\section{Agent Orange study blasted}

\section{Washington}

"MONUMENTALLY bungled or politically rigged" was how US Congressman Ted Weiss last week described a pilot study by the Centers for Disease Control (CDC) that tried to tackle the controversial question of whether wartime exposure to Agent Orange has damaged the health of Vietnam veterans.

Veterans' organizations claim that thousands of soldiers have suffered illeffects from handling Agent Orange and from exposure in areas where the dioxincontaining defoliant was sprayed in order to destroy cover for Vietnamese guerrilla fighters. But the CDC pilot study ended by concluding only that it would be impossible ever to untangle the effects of Agent Orange from many other factors affecting health. Of 34,000 veterans who have applied for compensation for health problems claimed to be caused by Agent Orange, only five have been successful

Weiss (Democrat, New York), chairman of the House of Representatives human resources and inter-governmental relations subcommittee was not satisified by the explanations delivered by CDC at a congressional hearing last week. He claimed that political pressure from the White House had led to a study "designed to be inconclusive". He is now demanding a new study by an independent organization and may introduce legislation to provide funds from Congress.

In a two-hour session of aggressive questioning, Vernon Houk, who led the CDC study, explained at the hearing that he had decided a full study was not worthwhile because most of the ground combat troops who did not handle or spray herbicides were not heavily exposed to dioxin, and that military records were inadequate to identify a large enough number of veterans who might have been exposed in order to validate a full-scale study.

A separate study, in which high levels of dioxin were found in the blood and adipose tissue of veterans heavily exposed to Agent Orange was cited as evidence that CDC may have missed a heavily contaminated subset of veterans. Philip Landrigan, director of environmental and occupational medicine at the Mount Sinai School of Medicine, New York, says that CDC must "dig further into the massive records which exist".

The conclusions of the CDC also conflict with those from a study carried out for the American Legion, which found that Agent Orange was significantly doserelated to a variety of health problems including benign fatty tumours, adult acne, skin rash with blisters, increased sensitivity to light and increased percentages of spouses' pregnancies that resulted in miscarriages. But CDC, the Congres- sional Office of Technology Assessment and the Agent Orange Working Group of the Cabinet Domestic Policy Council all claim that the American Legion study is seriously flawed.

Helen Gellband of OTA said at a separate hearing on Agent Orange held last week by the House subcommittee on hospitals and health care that most ground troops probably had relatively little exposure, and criticized the American Legion study for including any location up to 15 kilometres from the spray path while other data indicate that no herbicide would have travelled more than 2 kilometres from the spray line.

\section{EUROPEAN SPACE PROGRAMME}

\section{Munich \& Paris}

THE first shots were fired last week in what is likely to be a major budget battle at the European Space Agency (ESA) over how much more should be spent next year on the Hermes space shuttle and the Columbus space station. Last week, the West German government turned down Research Minister Heinz Riesenhuber's ambitious request for DM1,700 million (\$894 million) for space projects in 1990 . Nevertheless, Riesenhuber received a sizeable increase of DM175 million to DM1,300 million for 1990, which will allow West Germany to continue support for the time being for Hermes, Columbus and the heavy launcher Ariane 5.

Ministers from the 13 ESA member states voted at The Hague in November 1987 to establish a $\$ 12,800$ million manned space programme by the year 2000 . The three large projects form the core of the programme, but several optional projects, including telecommunications satellites, microgravity experiments and Earth observation projects have also been discussed. It is these optional projects that are in the greatest danger from future budget cuts by West Germany and other member states.

In the most immediate danger, said an official of the Research Ministry (BMFT), is the data-relay satellite ERS-2, which is supposed to be launched in 1996 and would link the proposed ESA polar platform with the Earth. The ESA council is expected in October to propose an 'enabling resolution' to construct ERS-2, and member states will have three months to respond. The Research Ministry expects Britain and France to veto the satellite. Italy, which very much wants to produce the optical communications technology involved, is expected to push for the satellite. ESA president Reimar Lüst said in March that he considered the
Gellband says that the CDC's final exposure assessment method was superior to the American Legion method and that the CDC's results were borne out by the results of serum dioxin testing.

While the scientific battle goes on, a court in May ruled in favour of Vietnam veterans over compensation for health problems caused by exposure to Agent Orange. The Veterans Administration (VA) had operated a strict rule that compensation can only be paid when a causal relationship is proved between a specific illness and Agent Orange exposure. But the San Francisco court ruled that Congress required only a "significant statistical association" between exposure and illness for compensation to be awarded.

Christine McGourty

\title{
Cap on German space budget
}

project to be essential.

Even Hermes and Columbus may be stretched out over more years than originally planned as a way to cut costs. Riesenhuber has sought to protect himself from cost overruns by promising that no more than 22 per cent of the BMFT budget would be spent on space projects. A BMFT official admitted that this could lead to delays.

The ESA director of space transportation systems, Jörg Feustel-Büechl, warned at an aerospace conference in Bonn in May of further cutbacks in the Hermes and Columbus programmes. Hermes is already "at the lower level of criticality", he said, and would become "just a technology programme" if it were cut back further.

European industry would be the biggest loser if optional ESA projects were to be cut and the other projects delayed. But member states have also put their pride on the line. Riesenhuber signed an agreement in Washington last week with Richard Truly, administrator of the national Aeronautics and Space Administration, for the launch of a West German spacelab mission called D-2 by the US space shuttle in February 1992, two months later than originally planned. D-2 is seen as an important milestone on the way to the space station.

Meanwhile, ESA president Reimar Lüst has been named as the next president of the Bonn-based Alexander von Humboldt Foundation. Lüst will take office on 22 September 1989, although he will remain president of ESA until 1990. Lüst, who is 66, follows Werner Heisenberg (1953-75), Feodor Lynen (1975-79) and Wolfgang Paul (1979-89) as president of the foundation, which brings hundreds of foreign researchers to West Germany every year on generous fellowships.

Steven Dickman \& Peter Coles 